\title{
Article \\ Casein Oligochitosan-Glycation by Transglutaminase Enhances the Anti-Inflammatory Potential of Casein Hydrolysates to the Lipopolysaccharide-Stimulated IEC-6 Cells
}

\author{
Na Chen ${ }^{1,2}$, Li Wang ${ }^{2,3}$, Qiang Zhang ${ }^{2,3}$, Xin-Huai Zhao ${ }^{2,3,4, * \mathbb{D}}$ and Jia Shi ${ }^{1, *}$ \\ 1 Key Laboratory of Dairy Science, Ministry of Education, Northeast Agricultural University, \\ Harbin 150030, China; chenna108@163.com \\ 2 School of Biology and Food Engineering, Guangdong University of Petrochemical Technology, \\ Maoming 525000, China; wangli7742@gdupt.edu.cn (L.W.); zhangqiang@gdupt.edu.cn (Q.Z.) \\ 3 Research Centre of Food Nutrition and Human Healthcare, Guangdong University of Petrochemical \\ Technology, Maoming 525000, China \\ 4 Maoming Branch, Guangdong Laboratory for Lingnan Modern Agriculture, Guangdong University of \\ Petrochemical Technology, Maoming 525000, China \\ * Correspondence: zhaoxh@gdupt.edu.cn (X.-H.Z.); shij@neau.edu.cn (J.S.); \\ Tel.: +86-668-2923716 (X.-H.Z.); +86-451-55190577 (J.S.)
}

check for updates

Citation: Chen, N.; Wang, L.; Zhang, Q.; Zhao, X.-H.; Shi, J. Casein Oligochitosan-Glycation by Transglutaminase Enhances the Anti-Inflammatory Potential of Casein Hydrolysates to the Lipopolysaccharide-Stimulated IEC-6 Cells. Nutrients 2022, 14, 686. https://doi.org/10.3390/ nu14030686

Academic Editor: Paola Nieri

Received: 28 December 2021

Accepted: 4 February 2022

Published: 6 February 2022

Publisher's Note: MDPI stays neutral with regard to jurisdictional claims in published maps and institutional affiliations.

Copyright: (C) 2022 by the authors. Licensee MDPI, Basel, Switzerland. This article is an open access article distributed under the terms and conditions of the Creative Commons Attribution (CC BY) license (https:// creativecommons.org/licenses/by/ $4.0 /)$.

\begin{abstract}
In this study, milk protein casein was glycated by oligochitosan through the catalysis of transglutaminase (TGase) and then hydrolyzed by trypsin. The obtained glycated casein hydrolysates (GCNH) were assessed for their anti-inflammatory activities, using the lipopolysaccharide (LPS)stimulated rat intestinal epithelial cells (IEC-6) as cell models and the casein hydrolysates (CNH) without TGase catalysis as controls. The results showed that GCNH had oligochitosan incorporation and thus possessed a glucosamine content of $5.74 \mathrm{~g} / \mathrm{kg}$ protein. In general, GCNH at dose levels of $25-100 \mu \mathrm{g} / \mathrm{mL}$ could elevate IEC-6 cell growth, and at dose levels of $25-50 \mu \mathrm{g} / \mathrm{mL}$, they were also able to alleviate the LPS-induced cytotoxicity by increasing cell viability efficiently. Although LPS caused clear inflammation in the LPS-stimulated cells, GCNH were capable of reducing the secretion of three pro-inflammatory mediators including interleukin-1 $\beta$ (IL-1 $\beta$ ), IL-6, and tumor necrosis factor- $\alpha$, or promoting the secretion of two anti-inflammatory mediators like IL-10 and transforming growth factor- $\beta$, demonstrating their anti-inflammatory activities to the stimulated cells. Moreover, GCNH also could down-regulate the expression of three inflammation-related proteins including TLR4, p-p38, and p-p65 in the stimulated cells, and thus possessed a capacity to suppress the phosphorylation of p38 and p65 proteins as well as to inactivate the NF- $\mathrm{kB}$ and MAPK signaling pathways. Additionally, a higher GCNH dose level consistently led to higher anti-inflammatory effect in the cells, while GCNH were always more potent than $\mathrm{CNH}$ at performing anti-inflammatory function targets. It is thus suggested that the TGase-catalyzed casein oligochitosan-glycation could enhance the anti-inflammatory activities of casein hydrolysates efficiently. TGase-catalyzed protein glycation thus might enhance the healthcare function of protein ingredients in the body.
\end{abstract}

Keywords: casein; oligochitosan; glycation; IEC-6 cells; lipopolysaccharide; anti-inflammatory effect

\section{Introduction}

Proteins as one main component of dietary foodstuffs are vital to the body, because they can provide the essential nutrients for life growth. In recent years, several protein modifications have been used to treat food proteins, aiming to improve protein functionalities or enlarge their application fields. In general, glycation, phosphorylation, and acetylation are the three main pathways, during which the saccharide, phosphate, and acetyl groups are covalently conjugated into amino acid residues of the protein targets, respectively. Subsequently, the modified proteins have changed configuration and more importantly functional properties. It was revealed that glycation, phosphorylation, and acetylation of 
proteins could improve these physicochemical properties of proteins like interfacial properties, solubility, surface hydrophobicity, and emulsification [1-3]. In addition, chemical modifications of proteins can also impact their digestion or bioactivities. For example, the performed glycation, phosphorylation, and acetylation of bovine $\alpha$-lactalbumin caused an attenuation of its allergic response [4], while the used phosphorylation of soy protein isolate (SPI) led to reduced digestion in the intestine [5]. Moreover, it was reported that the Maillard-type protein glycation could cause the loss of the essential amino acids (e.g., lysine and arginine) in proteins [6], and resulted in protein digestion in the gastrointestinal tract [7]. Thus, the transglutaminase (TGase)-mediated protein glycation using the saccharides with amino groups was explored in the previous studies [1,8-11]. The possible effect of this TGase-catalyzed glycation on the biological functions of food proteins is also concerned by the researchers. The results showed that this enzymatic protein glycation could promote the anti-oxidant capacity of corn gluten meal [2]. The results of our group also showed that TGase-mediated casein oligochitosan-glycation could endow the casein hydrolysates with better barrier protection, higher growth proliferation and differentiation in the rat intestinal epithelial cells (IEC-6 cells) [12,13]. However, whether the TGase-induced protein glycation has a positive or negative impact on the anti-inflammatory function of the target proteins or protein hydrolysates is still insufficiently investigated so far. Such a study using the TGase-mediated case in oligochitosan-glycation thus deserves our consideration.

Inflammation is a series of physiological responses that are stimulated by the immune system when the body is stimulated by the harmful substances. Infection and tissue damage are the typical triggers of inflammation. Lipopolysaccharide (LPS) is a major component in the cell wall of the Gram-negative bacteria, can be recognized by cells, and thus induces cells to produce pro-inflammatory cytokines, which finally damage cells [14]. LPS is thus considered to be an effective activator of the inflammatory response [15]. When LPS induces an inflammation in macrophages, the cells will release a large number of inflammatory markers such as cytokines, NO, prostaglandin E2 (PGE2), cyclooxygenase (COX-2), and others. The related inflammatory signaling pathways like NF- $\mathrm{kB}$ and MAPK are thus activated. It is recognized that inflammation is associated with many chronic diseases such as cancer, obesity, and gastrointestinal diseases. Fortunately, several food components, such as proteins [16], polysaccharides [17], and polyphenols, [18] are proven to have an ability to antagonize the induced inflammation. It was found that mung bean protein hydrolysates [19], sturgeon protein-derived peptides [20], and sea buckthorn flavonoids [21] were able to regulate the expression of inflammatory markers in the LPS-stimulated RAW 264.7 macrophages and then activate the relevant signaling pathways to exert an antiinflammatory effect. In addition, the polysaccharides from strawberry and mulberry juice showed anti-inflammatory effects on the LPS-stimulated spleen cells by inhibiting the secretion of inflammatory cytokines but enhancing the secretion of anti-inflammatory cytokines [22], while $\beta$-carotene exerted an anti-inflammatory effect on the LPS-stimulated IEC-6 cells via modulating autophagy and regulating signaling pathways [23]. Moreover, intestinal epithelial cells (such as IEC-6) have recently been used as cell models to investigate the intestinal inflammation of bovine lactoferrin [24] and echinacoside [25]. Thus, this cell model might also be suitable to investigate the anti-inflammatory effect of the oligochitosanglycated casein hydrolysates.

Cytokines are important in the development and maintenance of inflammation. Currently, tumor necrosis factor (TNF- $\alpha$ ) and interleukins (like IL-1 $\beta$, IL-6 and IL-10) are widely used to reflect the anti-inflammatory effects of food ingredients [26], because the LPS-induced cellular inflammation can increase the secretion of these inflammatory factors IL-6, IL-1 $\beta$, and TNF- $\alpha[20,27]$ but decrease the secretion of anti-inflammatory factors IL-10 and TGF- $\beta$ [25]. Additionally, the expression of nitric oxide synthase (iNOS) and COX-2 is also closely associated with inflammatory response because their overexpression will promote the secretion of NO and PGE2 and then trigger a cellular inflammatory response [28]. It is worth noting that these cytokines and non-cytokine mediators ultimately are regulated by the extracellular signaling pathways [29]. Typically, the nuclear factor 
kappa-B (NF- $\mathrm{B}$ ) and mitogen-activated protein kinase (MAPK) pathways are two common extracellular signaling pathways involved in cellular inflammation [30]. Subsequently, the anti-inflammatory effects of irisin and the protein hydrolysates of brewer's spent grain were evidenced to be mediated by the TLR4-NF-KB/MAPK signaling pathway [31,32].

In this study, the glycated casein hydrolysates obtained from the oligochitosanglycated casein were assessed for their anti-inflammatory potential in the LPS-stimulated IEC-6 cells, using the unglycated casein hydrolysates as a control. Several indices including cell viability, cytokine secretion, and the expression of critical proteins related to TLR4/p38 MAPK/NF-kB signaling pathway were measured, with a purpose to identify whether the performed TGase-mediated glycation had positive or negative influence on anti-inflammatory function of casein in the intestine.

\section{Materials and Methods}

\subsection{Materials and Reagents}

Casein (protein content of $911.2 \mathrm{~g} / \mathrm{kg}$, dry basis), Dulbecco's modified Eagle's medium (DMEM), 3-(4,5-dimethyl-2-thiazolyl)-2,5-diphenyltetrazolium bromide (MTT), and lipopolysaccharide (LPS, derived from E. coli O55:B5) were purchased from Sigma-Aldrich Chemical Co. (St. Louis, MO, USA). Oliogochitosan (75\% deacetylation and polymerization degree of 2-20) was obtained from Zhejiang Golden Shell Biochemical Co. (Hangzhou, Zhejiang, China). Microbial transglutaminase (TGase) with enzyme activity of 147 units (U)/g was the product of Jiangsu Yiming Fine Chemical Industry Co., Ltd. (Taixing, Jiangsu, China), while a trypsin (EC 3.4.21.4) preparation $(120 \mathrm{kU} / \mathrm{g}$ ) was purchased from Beijing Auboxing Biotechnology Co. (Beijing, China). Trypsin-EDTA (ethylenediamine tetra-acetic acid) and bovine insulin were provided by Solarbio Technology Ltd. (Beijing, China), while fetal bovine serum (FBS) was bought from Wisent Inc. (Montreal, QC, Canada).

Five enzyme-linked immunosorbent assay (ELISA) kits [rat tumor necrosis factor- $\alpha$ (TNF- $\alpha$ ), transforming growth factor- $\beta$ (TGF- $\beta$ ), and three interleukins (IL-1 $\beta$, IL- 6 , and IL-10)] were bought from Nanjing Jiancheng Institute of Biological Engineering (Nanjing, China), while the protein assay kit (BCA) and radio immunoprecipitation assay (RIPA) lysis buffer were provided by Beyotime Biotechnology Institute (Shanghai, China). The primary antibodies of p-p65 (phospho-NF- $\mathrm{kB}$ p65, Bioss bs-0982R), TLR4 (Bioss bs-20594R) and $\beta$-actin (Bioss bs-0061R) were provided by Biosynthesis Biotechnology Inc. (Beijing, China), while phosphorylated p38 MAPK (\#4511) and the goat anti-rabbit HRP secondary antibody (\#7074) were obtained from Cell Signaling Technology (Danvers, MA, USA).

\subsection{Sample Preparation}

The oligochitosan-glycated casein was prepared as previously described [33]. In brief, casein was dispersed in water at $\mathrm{pH} 7.5$ to reach $80 \mathrm{~g} / \mathrm{L}$. Oligochitosan was added into casein solution to reach the molar ratio of acyl donor to oligochitosan acceptor 1:3 and final protein content of $50 \mathrm{~g} / \mathrm{L}$. TGase (10 U/g protein) was added to perform the reactions at $37^{\circ} \mathrm{C}$ for $3 \mathrm{~h}$. The mixture was then heated at $85^{\circ} \mathrm{C}$ for $5 \mathrm{~min}$, cooled rapidly, and precipitated by adding $0.1 \mathrm{~mol} / \mathrm{L} \mathrm{HCl}$ solution to $\mathrm{pH} 4.5$. The obtained precipitate (oligochitosan-glycated casein) was washed twice with water at $\mathrm{pH} 4.5$, neutralized to $\mathrm{pH}$ 7.0, and then freeze-dried. Casein was also mixed with oligochitosan but without TGase addition, and then treated similarly to obtain control casein.

The control casein and glycated casein $(50 \mathrm{~g} / \mathrm{L})$ were dispersed in water at $\mathrm{pH}$ 7.0, and then hydrolyzed at $37^{\circ} \mathrm{C}$ for $4 \mathrm{~h}$ with trypsin addition of $7 \mathrm{kU} / \mathrm{g}$ protein. After the hydrolysis, the solutions were heated at $100{ }^{\circ} \mathrm{C}$ for $5 \mathrm{~min}$, cooled rapidly to $20^{\circ} \mathrm{C}$, neutralized to $\mathrm{pH} 7.0$, and centrifuged at $5000 \times g$ for $20 \mathrm{~min}$. The obtained supernatants were collected and lyophilized to obtain the respective casein hydrolysates $(\mathrm{CNH})$ and oligochitosan-glycated casein hydrolysates (GCNH). 


\subsection{Assays of Protein and Glucosamine Contents}

Protein content was determined by the Kjeldahl method with a conversion factor of 6.38 [34]. Glucosamine content was determined according to the Elson-Morgan method with minor modifications [35]. In detail, the sample of $0.2 \mathrm{~g}$ was hydrolyzed with $6 \mathrm{~mol} / \mathrm{L}$ $\mathrm{HCl}$ of $2.5 \mathrm{~mL}$ at $100{ }^{\circ} \mathrm{C}$ for $4 \mathrm{~h}$, cooled to $20^{\circ} \mathrm{C}$, neutralized to $\mathrm{pH} 7.0$, and diluted with water into $25 \mathrm{~mL}$. Acetylacetone solution (acetylacetone of $1 \mathrm{~mL}$ plus $0.5 \mathrm{~mol} / \mathrm{L} \mathrm{NaHCO}_{3}$ of $24 \mathrm{~mL}$ ) of $1 \mathrm{~mL}$ was added to the hydrolysates of $5 \mathrm{~mL}$, heated in a boiling water bath for $25 \mathrm{~min}$, cooled rapidly, mixed with p-2-dimethylaminobenzaldehyde solution of $1 \mathrm{~mL}$ $(0.8 \mathrm{~g}$ of p-dimethylaminobenzaldehyde in $12 \mathrm{~mol} / \mathrm{L} \mathrm{HCl}$ of $15 \mathrm{~mL}$ and aldehyde-free ethanol of $15 \mathrm{~mL}$ ) and aldehyde-free ethanol of $3 \mathrm{~mL}$, and then kept at $60{ }^{\circ} \mathrm{C}$ for $1 \mathrm{~h}$. The absorbance value was measured at $525 \mathrm{~nm}$ by a UV spectrophotometer (UV-2600, Shimadzu, Kyoto, Japan). Glucosamine content (g/kg protein) was calculated using a standard curve generated from a series of standard glucosamine solutions.

\subsection{Cell Line and Cell Culture}

As recommended, IEC-6 cells provided by the American Type Culture Collection (Rockville, MD, USA) were cultured at $37^{\circ} \mathrm{C}$ and $5 \% \mathrm{CO}_{2}$ in the DMEM medium fortified with $4 \mathrm{mmol} / \mathrm{L}$ L-glutamine, $4.5 \mathrm{~g} / \mathrm{L}$ glucose, $1.5 \mathrm{~g} / \mathrm{L} \mathrm{NaHCO}_{3}, 1 \mathrm{mmol} / \mathrm{L}$ sodium pyruvate, $100 \mathrm{U} / \mathrm{L}$ bovine insulin and $10 \%$ fetal bovine serum. The medium was replaced twice a week, while the cells were fused to $80 \%$ for the later experiments.

\subsection{Assays of Cell Viability}

The classic MTT method was employed to determine the potential cytotoxicity of the two hydrolysates CNH and GCNH on IEC- 6 cells. In brief, the cells $\left(1 \times 10^{4}\right.$ cells / well) were seeded into 96-well plates for $24 \mathrm{~h}$, and then serum-starved for $12 \mathrm{~h}$. After this treatment, the cells were incubated with or without $\mathrm{CNH}$ and GCNH for $12-48 \mathrm{~h}$, using the sample doses ranging from 25 to $100 \mu \mathrm{g} / \mathrm{mL}$. After removal of the medium, MTT solution $(0.5 \mathrm{mg} / \mathrm{mL})$ of $20 \mu \mathrm{L}$ was added to each well, while the cells were incubated for $4 \mathrm{~h}$. After a careful aspiration of the medium, $100 \mu \mathrm{L}$ of dimethyl sulfoxide (DMSO) was added to dissolve the generated formalin crystals, while the value of optical density (OD) was detected at $490 \mathrm{~nm}$ by a microplate reader (Bio-Rad Laboratories, Hercules, CA, USA). The control cells without sample treatment were set at $100 \%$ cell viability, as previously described [13].

\subsection{Assay of LPS Cytotoxicity}

Briefly, IEC- 6 cells at a density of $1 \times 10^{4}$ cells / well were seeded onto 96-well plates, incubated for $24 \mathrm{~h}$, and serum-starved for $12 \mathrm{~h}$. After that, the cells were incubated with or without CNH and GCNH at the doses of 25-50 $\mu \mathrm{g} / \mathrm{mL}$ for 12 and $24 \mathrm{~h}$ and exposed to $10 \mu \mathrm{g} / \mathrm{mL}$ LPS for $24 \mathrm{~h}$. The medium was discarded, while $0.5 \mathrm{mg} / \mathrm{mL}$ of MTT solution was added to each well with an incubation time of $4 \mathrm{~h}$. DMSO of $100 \mu \mathrm{L}$ was added to each well after a careful aspiration of the medium. The OD value was detected at $490 \mathrm{~nm}$ by the same microplate reader. The control cells without any treatment were set with $100 \%$ cell viability.

\subsection{Assays of Cytokine Secretion}

The secretion levels of three inflammatory mediators (IL-1 $\beta$, IL- 6 , and TNF- $\alpha$ ) and two anti-inflammatory mediators (IL-10 and TGF- $\beta$ ) were measured with the respective enzyme-linked immunosorbent assay (ELISA) kits. In brief, IEC-6 cells $\left(1 \times 10^{5}\right.$ cells $/ \mathrm{mL}$, $2 \mathrm{~mL} /$ well) were loaded into 6-well plates for $24 \mathrm{~h}$ and incubated in serum-free medium for $12 \mathrm{~h}$. After discarding the medium, $\mathrm{CNH}$ and GCNH at the doses of $25-50 \mu \mathrm{g} / \mathrm{mL}$ were added into each well to treat the cells for 12 and $24 \mathrm{~h}$, followed by LPS exposure $(10 \mu \mathrm{g} / \mathrm{mL})$ of the cells for $24 \mathrm{~h}$. Afterwards, the supernatants were collected by a centrifugation at $500 \times g$ for $20 \mathrm{~min}$, while the cytokine levels were assessed using the instructions provided by the kit manufacturers. 


\subsection{Assays of Protein Expression}

In brief, IEC- 6 cells were plated into cell bottles for $24 \mathrm{~h}$ and incubated in serum-free medium for $12 \mathrm{~h}$. After this treatment, the cells were incubated with or without $\mathrm{CNH}$ and GCNH at the doses of $25-50 \mu \mathrm{g} / \mathrm{mL}$ for 12 and $24 \mathrm{~h}$, and then exposed to $10 \mu \mathrm{g} / \mathrm{mL}$ LPS for $24 \mathrm{~h}$. After discarding the supernatants, the cells were washed three times with ice-PBS and lysed on ice for 30 min by adding lysis buffer containing protease inhibitor. The lysed cells were centrifuged at $12,000 \times g$ for $5 \mathrm{~min}$ at $4{ }^{\circ} \mathrm{C}$ to obtain total protein. A BCA protein analysis kit was used to assess the protein content of the samples. The equivalent samples with protein of $10 \mu \mathrm{g}$ were subjected to $12 \%$ SDS-PAGE and subsequently transferred onto the PVDF membranes. After blocking with 5\% skim milk in TBST $(1 \times$ TPBS containing $0.1 \%$ Tween-20) for $2 \mathrm{~h}$ at $37^{\circ} \mathrm{C}$, the membranes were kept overnight at $4{ }^{\circ} \mathrm{C}$ with primary antibody $\beta$-actin (1:1000 dilution), TLR4 (1:1000 dilution), p-p38 MAPK (1:1000 dilution) and p-p65 (1:500 dilution). Afterwards, the membranes were washed three times with TBST and incubated for $2 \mathrm{~h}$ at $37^{\circ} \mathrm{C}$ with the peroxidase-conjugated secondary antibody (1:1000 dilution). The membranes were washed with TBST three times, while the immunolabeled proteins were detected with enhanced chemiluminescence reagents. Image J software (National Institutes of Health, Bethesda, MD, USA) was used for the quantitative analysis of protein bands.

\subsection{Statistical Analysis}

All experimental results from three independent experiments were expressed as the mean values \pm standard deviations. Statistical analysis (one-way analysis of variance, ANOVA) and Duncan multi-interval test were performed using the IBM Statistical Products and Services Solutions (SPSS) 26.0 software. The $p<0.05$ was considered statistically significant.

\section{Results}

\subsection{Effect of the Two Hydrolysates on Cell Growth}

The results showed that the conjugated glucosamine amount of GCNH was $5.74 \mathrm{~g} / \mathrm{kg}$ protein, suggesting that GCNH contained oligochitosan-glycated peptides. Thereby, it was possible that GCNH had different anti-inflammatory potentials than $\mathrm{CNH}$ in the target cells, because of the occurred oligochitosan glycation. When IEC-6 cells were incubated with $\mathrm{CNH}$ and GCNH at three doses of $25-100 \mu \mathrm{g} / \mathrm{mL}$ for three set time periods $(12-48 \mathrm{~h})$, all treated cells were detected with viability values larger than $100 \%$ (Figure 1), indicating that the two samples did not have a toxic effect on cells. To be more specific, when the cells were incubated with $\mathrm{CNH}$ and GCNH for $12 \mathrm{~h}$, viability values were measured to be 106.7-115.2\% and 112-131.9\%, respectively (Figure 1a). A longer cell incubation time of $24 \mathrm{~h}$ would promote the viability values to $108.2-122 \%$ and $119.9-135.4 \%$ (Figure $1 \mathrm{~b}$ ), while another incubation time of $48 \mathrm{~h}$ caused viability values of $104.7-109.9 \%$ and $111.3-125.7 \%$, respectively (Figure 1c). All data suggested that the two hydrolysates had a favorable but not suppressing effect on cell growth in all cases. Data comparison also demonstrated that GCNH had higher potential than $\mathrm{CNH}$ to promote cell growth, evidencing that the performed oligochitosan glycation caused an enhanced bioactivity for casein. At the same time, a cell treatment time of $48 \mathrm{~h}$ caused a lower viability values than that of 12 and $24 \mathrm{~h}$, and more importantly, the doses of $25-50 \mu \mathrm{g} / \mathrm{mL}$ generally led to higher viability values than the dose of $100 \mu \mathrm{g} / \mathrm{mL}$. Thus, two cell treatment times of 12 and $24 \mathrm{~h}$ together with two sample doses of 25 and $50 \mu \mathrm{g} / \mathrm{mL}$ were used in later evaluations to clarify and compare the anti-inflammatory activities of $\mathrm{CNH}$ and $\mathrm{GCNH}$. 

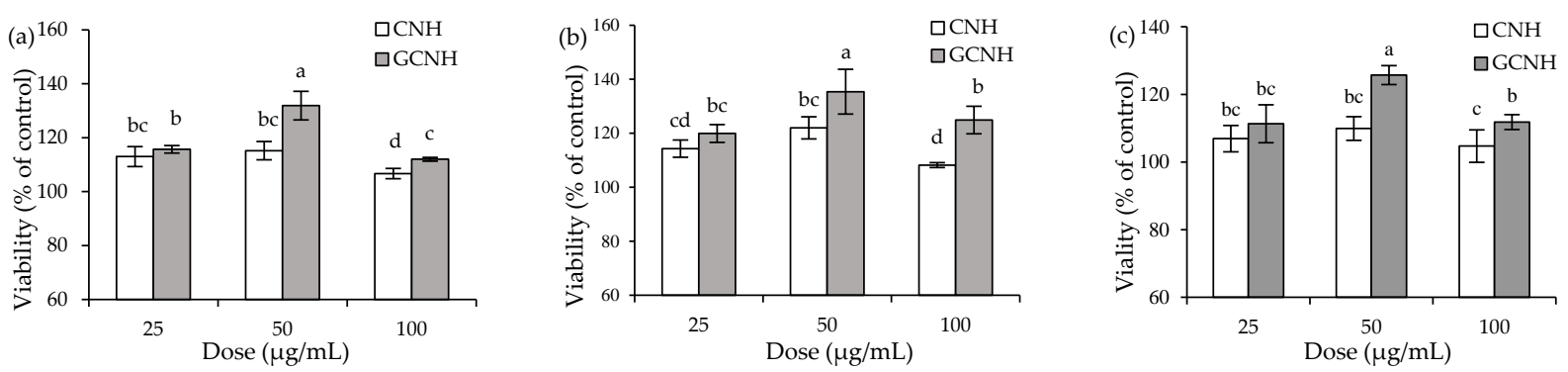

Figure 1. Viability values of the IEC-6 cells incubated with casein hydrolysates $(\mathrm{CNH})$ and oligochitosan-glycated $\mathrm{CNH}(\mathrm{GCNH})$ at doses of $25-100 \mu \mathrm{g} / \mathrm{mL}$ for 12 (a), 24 (b), and $48 \mathrm{~h}$ (c), respectively. Different lowercase letters above the columns indicate that the mean values differ significantly $(p<0.05)$.

\subsection{Effect of the Two Hydrolysates on the LPS-Induced Cellular Injury}

Using the mentioned conditions to treat the cells or expose the cells with $10 \mu \mathrm{g} / \mathrm{mL}$ LPS for $24 \mathrm{~h}$, the final results indicated that LPS caused cytotoxic effect on the cells, but the target hydrolysates could alleviate the LPS-caused adverse effect (Figure 2). In detail, the cells with LPS exposure but without hydrolysate treatment showed viability values of $83.6 \%(12 \mathrm{~h})$ and $88.6 \%(24 \mathrm{~h})$, reflecting the LPS-induced cell injury. When the cells were first treated with $\mathrm{CNH}$ and then exposed to LPS, they were measured with viability values of $94.9-103.9 \%(12 \mathrm{~h})$ and $98.9-105.3 \%(24 \mathrm{~h})$. At the same time, if the cells were pre-treated with GCNH, they were measured with viability values of $99.9-107.5 \%(12 \mathrm{~h})$ and $107.1-114.5 \%$ ( $24 \mathrm{~h}$ ). The data proved that the two hydrolysates alleviated the LPS-induced cell injury in all cases, and thus possessed protective effect on the cells. Generally, higher hydrolysate dose and longer treatment time consistently led to higher viability values. More importantly, GCNH were more active than $\mathrm{CNH}$ in protecting the LPS-induced cell injury, verifying that the performed oligochitosan glycation of casein caused higher bioactivity for GCNH.
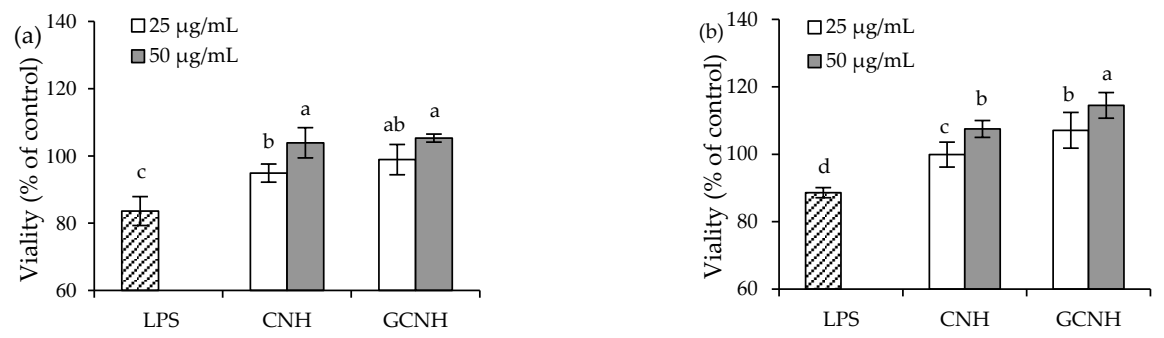

Figure 2. Viability values of the IEC-6 cells incubated with casein hydrolysates $(\mathrm{CNH})$ and oligochitosan-glycated $\mathrm{CNH}(\mathrm{GCNH})$ at doses of $25-50 \mu \mathrm{g} / \mathrm{mL}$ for 12 (a) and 24 (b) followed by LPS treatment $(10 \mu \mathrm{g} / \mathrm{mL})$ of $24 \mathrm{~h}$. Different lowercase letters above the columns indicate that the mean values differ significantly $(p<0.05)$.

\subsection{Effect of Two Hydrolysates on the Secretion of Inflammatory Mediators}

Secretion levels of three inflammatory mediators (IL-1 $\beta$, IL-6, and TNF- $\alpha$ ) were detected in the supernatants collected from the treated cells (Figures 3 and 4), to clarify whether $\mathrm{CNH}$ and $\mathrm{GCNH}$ had different effects on the cells in cytokine secretion. First, the two hydrolysates in IEC-6 cells did not promote IL-6 secretion (Figure 3), indicating they did not cause inflammation in the cells. However, the two hydrolysates in the LPSinduced cells showed a capacity to inhibit the secretion of the three inflammatory mediators (Figure 4). Specifically, the LPS-induced cells showed IL-1 $\beta$, IL-6, and TNF- $\alpha$ secretion of 32.2-33.0, 168.5-173.5, and 138.8-148.8 pg/mL, while the CNH-treated cells (12 h) after LPS stimulation showed reduced IL-1 $\beta$, IL-6, and TNF- $\alpha$ secretion of 25.7-28.4, 120.6-121.2, and $118.7-119.4 \mathrm{pg} / \mathrm{mL}$, respectively. In addition, the GCNH-treated cells $(12 \mathrm{~h})$ after LPS stimulation had much reduced IL-1 $\beta$, IL-6, and TNF- $\alpha$ secretion of 19.3-21.7, 96.0-112.2, and 
84.8-93.8 pg/mL, respectively. Using a $24 \mathrm{~h}$ of cell treatment time with the two hydrolysates, the CNH-treated cells after LPS stimulation showed further reduction in IL-1 $\beta$, IL-6, and TNF- $\alpha$ secretion (19.0-22.4, 116.8-122.2, and 112.4-112.8 pg/mL), while the GCNH-treated cells after LPS stimulation had the lowest secretion in IL-1 $\beta$, IL-6, and TNF- $\alpha$ (16.3-23.2, 89.8-97.2, and 91.2-105.7 pg/mL). These data proved consistently that the two hydrolysates had an anti-inflammatory effect on the LPS-induced cells by inhibiting the secretion of the three inflammatory mediators, and more interestingly, GCNH were more capable of reducing inflammatory cytokines secretion than $\mathrm{CNH}$. It was thus suggested that the employed oligochitosan glycation of casein led to enhanced anti-inflammatory potential for the obtained GCNH in the LPS-induced cells.
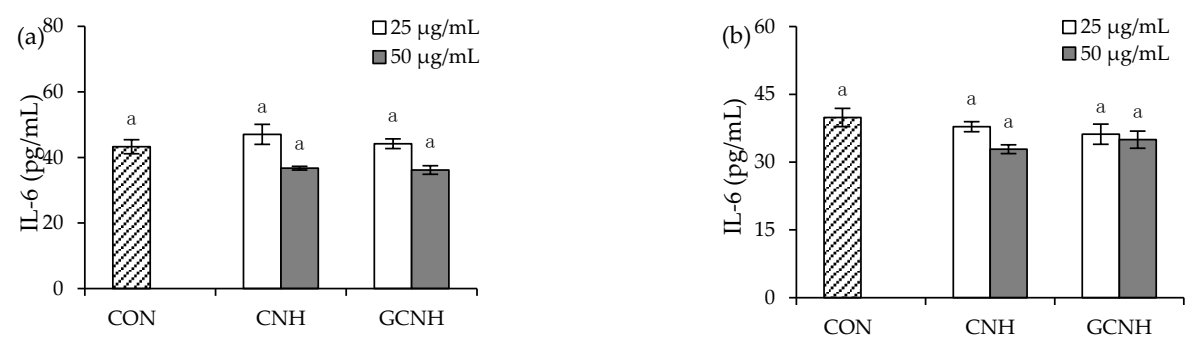

Figure 3. IL-6 secretion in the IEC-6 cells incubated with the casein hydrolysates $(\mathrm{CNH})$ and oligochitosan-glycated $\mathrm{CNH}(\mathrm{GCNH})$ at doses of $25-50 \mu \mathrm{g} / \mathrm{mL}$ for 12 (a) and $24 \mathrm{~h}$ (b). The abbreviation "CON" denotes the control cells without sample treatment, while different lowercase letters above the columns indicate that the mean values differ significantly $(p<0.05)$.
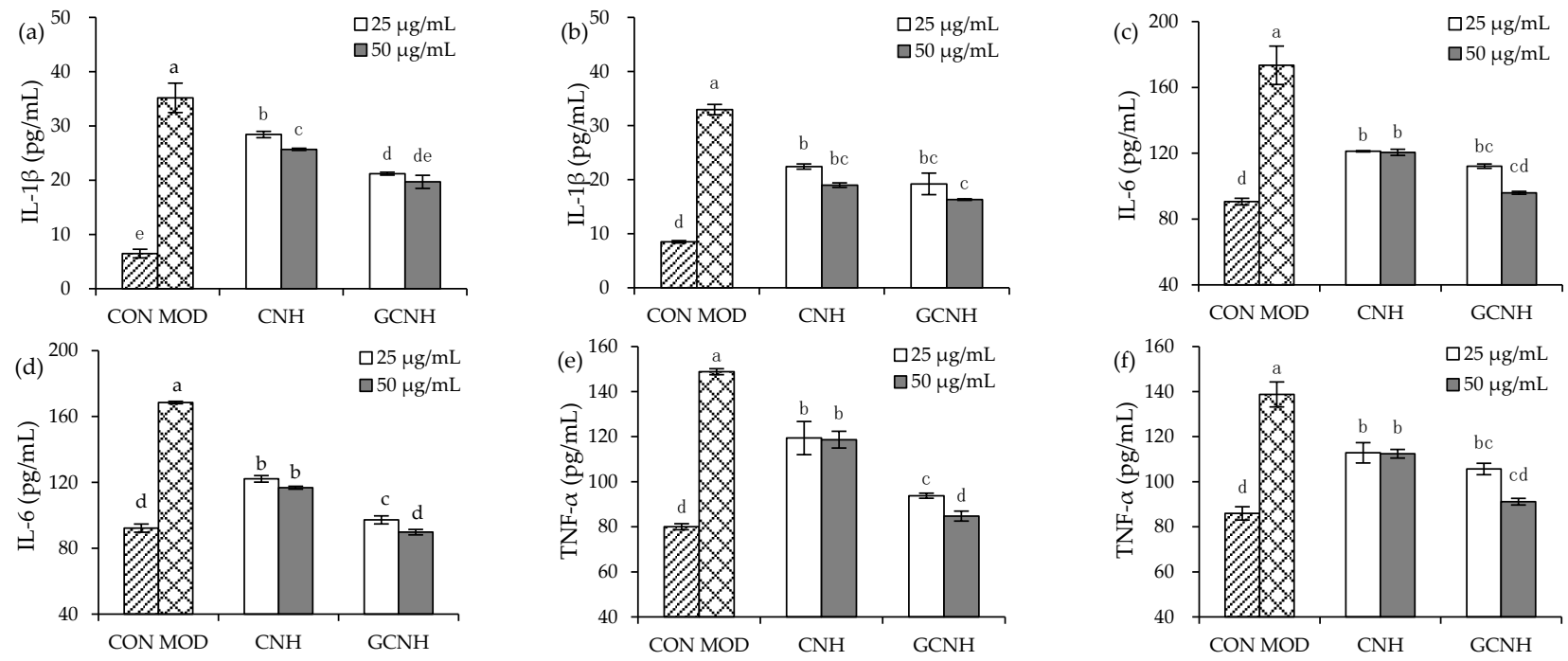

Figure 4. Secretion levels of three pro-inflammatory mediators IL-1 $\beta(\mathbf{a}, \mathbf{b})$, IL-6 (c,d), and TNF- $\alpha$ $(\mathbf{e}, \mathbf{f})$ in the IEC-6 cells incubated with casein hydrolysates $(\mathrm{CNH})$ and oligochitosan-glycated $\mathrm{CNH}$ $(\mathrm{GCNH})$ at doses of $25-50 \mu \mathrm{g} / \mathrm{mL}$ for $12(\mathbf{a}, \mathbf{c}, \mathbf{e})$ and $24 \mathrm{~h}(\mathbf{b}, \mathbf{d}, \mathbf{f})$, respectively, followed by LPS treatment $(10 \mu \mathrm{g} / \mathrm{mL})$ of $24 \mathrm{~h}$. The abbreviations "CON" and "MOD" stand for the control and LPS-stimulated cells, respectively, while different lowercase letters above the columns indicate that the mean values differ significantly $(p<0.05)$.

\subsection{Effect of Two Hydrolysates on the Secretion of Anti-Inflammatory Mediators}

Compared with the secretion of the two anti-inflammatory mediators IL-10 and TGF- $\beta$ in the control cells, the present results showed that LPS caused lower secretion in IL10 and TGF- $\beta$ in the LPS-induced cells (Figure 5), because IL-10 (or TGF- $\beta$ ) level was decreased from $21.3-22.2$ to $6.7-8.1 \mathrm{pg} / \mathrm{mL}$ (or from 39.7-47.4 to 15.4-18.8 pg/mL). On the contrary, $\mathrm{CNH}$ and GCNH consistently promoted the secretion of IL-10 and TGF- $\beta$ in the LPS-induced cells. In detail, when the cells were treated by $\mathrm{CNH}$ for $12 \mathrm{~h}$ before the 
LPS exposure, they were measured with increased IL-10 (10.27-14.46 pg/mL) and TGF- $\beta$ (24.35-27.19 pg/mL) secretion. Meanwhile, if the cells were pre-treated with GCNH for $12 \mathrm{~h}$ before the LPS exposure, they were measured to have distinctly increased IL-10 and TGF- $\beta$ secretion of 13.6-15.6 and 25.8-28.6 pg/mL, respectively. In addition, the CNH-treated cells $(24 \mathrm{~h})$ after the LPS exposure had much secretion increases in IL-10 and TGF- $\beta$ (13.0-14.7 and $18.5-22.3 \mathrm{pg} / \mathrm{mL}$ ), while the GCNH-treated cells $(24 \mathrm{~h})$ after the LPS exposure had the highest secretion increases in IL-10 and TGF- $\beta$ (14.5-17.9 and 19.5-34.6 pg/mL). The data changes demonstrated that the two hydrolysates had an anti-inflammatory effect on the LPS-induced cells in all cases because they consistently enhanced the secretion of IL-10 and TGF- $\beta$. Further data comparison also suggested that GCNH were more efficient than $\mathrm{CNH}$ at promoting the secretion of IL-10 and TGF- $\beta$. This fact evidenced again that the performed oligochitosan glycation of casein could enhance the anti-inflammatory activity of GCNH, via endowing GCNH with higher potential to promote the secretion of anti-inflammatory mediators IL-10 and TGF- $\beta$.
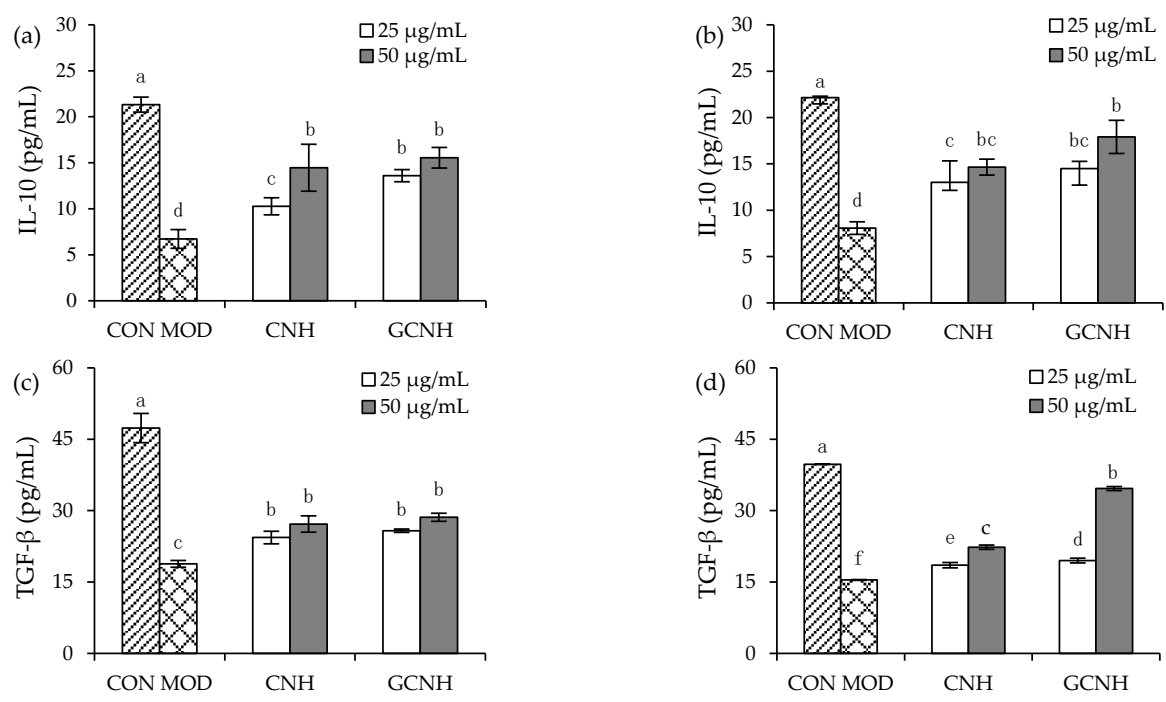

Figure 5. Secretion levels of two anti-inflammatory mediators IL-10 (a,b) and TGF- $\beta(\mathbf{c}, \mathbf{d})$ in the IEC-6 cells incubated with the casein hydrolysates $(\mathrm{CNH})$ and oligochitosan-glycated $\mathrm{CNH}(\mathrm{GCNH})$ at doses of $25-50 \mu \mathrm{g} / \mathrm{mL}$ for $12(\mathbf{a}, \mathbf{c})$ and $24 \mathrm{~h}(\mathbf{b}, \mathbf{d})$, respectively, followed by LPS treatment $(10 \mu \mathrm{g} / \mathrm{mL})$ of $24 \mathrm{~h}$. The abbreviations "CON" and "MOD" stand for the control and LPS-stimulated cells, respectively, while different lowercase letters above the columns indicate that the mean values differ significantly $(p<0.05)$.

\subsection{Expression Changes of the Signaling Pathway-Related Proteins}

To further clarify whether $\mathrm{CNH}$ and GCNH had anti-inflammatory activities to the LPS-induced cells, the expression levels of three proteins TLR4, p-p65 and p-p38 from the TLR4-NF- $\mathrm{KB} / \mathrm{MAPK}$ signaling pathway, which is regarded to play a critical role in cellular inflammation, were thus detected. The immunoblotting results (Figures 6 and 7 ) showed that when the ratios of TLR4/ $\beta$-actin, $p$-p65/ $\beta$-actin, and p-p38/ $\beta$-actin were used as three evaluation indicators, the two hydrolysates were capable of down-regulating the expression levels of TLR4, p-p65 and p-p38. Compared with the control cells, the LPSinduced cells had up-regulated expression for TLR4, p-p65 and p-p38 by 1.81-, 1.86-, and 1.07-folds, respectively. Meanwhile, the CNH-treated cells after LPS stimulation showed a reduced expression for TLR4, p-p65, and p-p38 (1.59-, 1.46-, and 0.68-folds), whilst the GCNH-treated cells after the LPS stimulation showed the lowest expression for TLR4, p-p65 and p-p38 (1.05-, 0.96-, and 0.50-folds). The p-p65 and p-p38 are key proteins of cellular inflammation in the NF- $\mathrm{B}$ and MAPK signaling pathways, respectively. Thus, the western-blotting results revealed that the two hydrolysates could inhibit the LPS-induced pathway activation by down-regulating the critical proteins TLR4, p-p65, and p-p38, and thus possessed anti-inflammatory activities to the induced cells. In addition, GCNH led 
to a higher reduction in the expression of the three proteins in the induced cells, implying that GCNH might have higher anti-inflammatory activity than CNH. In other words, the performed oligochitosan glycation showed the ability to increase the anti-inflammatory potential of GCNH.

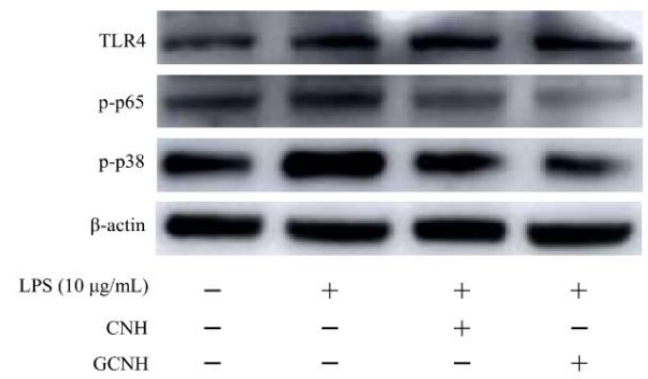

Figure 6. Expression of three proteins TLR4, p-p65, p-p38 in the IEC-6 cells incubated with or without casein hydrolysates $(\mathrm{CNH})$ and oligochitosan-glycated $\mathrm{CNH}(\mathrm{GCNH})$ at doses of $25-50 \mu \mathrm{g} / \mathrm{mL}$ for $24 \mathrm{~h}$ or LPS treatment $(10 \mu \mathrm{g} / \mathrm{mL})$ of $24 \mathrm{~h}$.
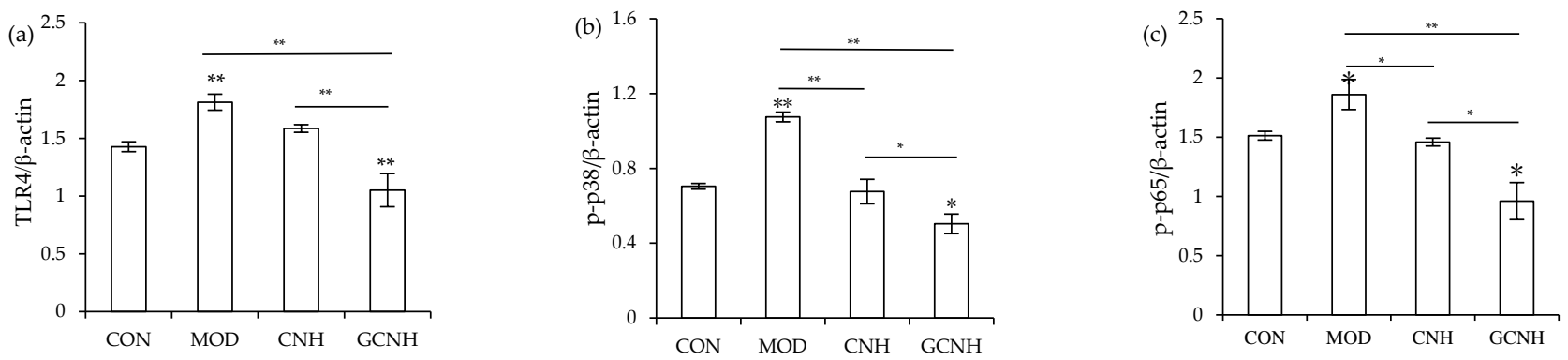

Figure 7. The calculated ratios of TLR4/ $\beta$-actin (a), p-p38/ $\beta$-actin (b), and p-p65/ $\beta$-actin (c) in the IEC-6 cells incubated with or without casein hydrolysates $(\mathrm{CNH})$ and oligochitosan-glycated $\mathrm{CNH}$ $(\mathrm{GCNH})$ at doses of $25-50 \mu \mathrm{g} / \mathrm{mL}$ for $24 \mathrm{~h}$ or LPS treatment $(10 \mu \mathrm{g} / \mathrm{mL})$ of $24 \mathrm{~h}$. The abbreviations "CON" and "MOD" stand for the control and LPS-stimulated cells, respectively, while the labeled asterisks indicate a significant difference ${ }^{*} p<0.05$ and $\left.{ }^{* *} p<0.01\right)$.

\section{Discussion}

Food proteins are essential for body growth and health maintenance, as they provide both nutrition and bioactivities in the body. Protein glycation could alter the properties of the protein targets efficiently. In referring to the protein glycation of the Maillard-type, it was evidenced that this glycation could improve solubility, rheology, emulsification, thermal stability, foaming, and gelation of the treated proteins [36,37], or enhance the antibacterial, anti-oxidant, ACE-inhibitory, and anti-inflammatory activities of the peptides [38]. Unfortunately, a previous study also found that lactose glycation of casein led to lower immune potential for the casein hydrolysates [4]. TGase can also catalyze the reaction between proteins and amino sugars, causing another reaction type of protein glycation (i.e., protein glycation of TGase-type). The results indicated that TGase catalyzed the glycation of ferritin by oligochitosan, while the grafted amount of amino sugar was $5.6-8.3 \mathrm{~g} / \mathrm{kg}$ protein [39]. Moreover, the glycated ferritin obtained higher thermal stability because its maximum peak temperature was increased from $73.12{ }^{\circ} \mathrm{C}$ to $78.16{ }^{\circ} \mathrm{C}$ [39]. In addition, when TGase was used to catalyze the glycation of casein by the degraded chitosan, the surface hydrophobicity, in vitro digestibility, water-binding, solubility, and rheological properties of the modified casein were improved $[1,40]$. Therefore, whether the TGase-type protein glycation induced an alteration in protein bioactivities aroused extensive attention in the past years. It was observed that the chitosan-glycation of hemoglobin by TGase resulted in respective $11.06 \%$ and $30.49 \%$ increases in anti-oxidant activity and iron bioavailability [41], while the glucosamine-glycation of bovine $\beta$-lactoglobulin by TGase led to a weakened allergic reactivity including a reduced $\operatorname{IgG/IgE}$ binding capacity [4]. More importantly, 
the previous results from our groups also indicated that oligochitosan-glycation of casein by TGase brought about higher barrier protection for the casein hydrolysates in IEC- 6 cells [6,33]. All results thus supported that GCNH had higher bioactivity than CNH with which to alleviate the LPS-induced cell inflammation in the target cells because GCNH were yielded from the enzymatic hydrolysis of the oligochitosan-glycated casein, while the oligochitosan molecules were evidenced to be conjugated into the Gln residues of the glycated casein hydrolysates [33].

It was fully proved that protein hydrolysates had various bioactivities, and thus could perform critical anti-oxidant, anti-microbial, anti-hypertensive, and anti-diabetic effects [42]. For example, when camel milk protein was hydrolyzed under the catalysis of three proteases like alkaline protease, $\alpha$-chymosin and papain, the yielded protein hydrolysates showed anti-oxidant activity to scavenge DPPH/ABTS radicals and to reduce iron ions [43]. The isolated components from camel protein hydrolysates by protease $\mathrm{K}$ were reported to have ACE inhibitory activity [44], while the albumin-derived peptide KLPGF was confirmed to have anti-diabetic potential through inhibiting $\alpha$-glucosidase and $\alpha$-amylase [45]. In addition, the hydrophobic peptides separated from soybean protein hydrolysates were found to have an anti-cancer effect [46]. It has been well-established that protein hydrolysates can regulate the immune response in cells and tissues. It was observed that the hydrolysates from shark proteins were able to enhance the phagocytosis activity of macrophages, or to increase the levels of IgA as well as IFN- $\gamma$, TNF- $\alpha$, IL-10, IL-4 and IL-6 in small intestine tissues, confirming the immuno-modulatory effect of the hydrolysates [47]. Furthermore, the pea protein hydrolysates could enhance the phagocytosis activity of mouse macrophages, or stimulate intestinal cells to produce IL-6 [48]. Inflammation is a transient phenomenon of the immune response, and the anti-inflammatory effects of protein hydrolysates have been assessed sufficiently. For example, the sturgeon protein peptides showed anti-inflammatory effect on the LPS-induced macrophages by reducing the release of NO, IL- 6 , and IL- $1 \beta$, or inhibiting the activation of MAPK signaling pathway [20,49]. It was found that casein glycopeptide hydrolysates could neutralize LPS by directly binding to LPS or inhibiting the binding of LPS to the TLR4/MD2 complex, causing an inactivation of TLR4/MyD88/NF- $\mathrm{KB}$ and less production of TNF- $\alpha$ and IL$1 \beta$ [50]. Casein glycopeptide hydrolysates in the LPS-stimulated RAW264.7 cells were thus regarded to possess anti-inflammatory function by modulating the TLR4-mediated inflammatory responses [50]. Another previous study also confirmed that whey protein hydrolysates by pepsin, trypsin, chymotrypsin and peptidase had anti-inflammatory effect on the LPS-induced inflammation in respiratory epithelial cells, through inhibiting the secretion of pro-inflammatory mediator IL-8 [51]. In this study, the target GCNH also belonged to protein hydrolysates, and reasonably had similar anti-inflammatory function in the LPS-stimulated IEC-6 cells. However, due to the oligochitosan conjugation into casein molecules, GCNH reasonably contained some glycated peptides. Shared result consistence with these reported studies [50,52,53], this study also observed that GCNH had ant-inflammatory function in the LPS-stimulated IEC-6 cells, and also showed higher potential than $\mathrm{CNH}$.

Inflammatory response can induce the formation of cytokines and inflammatory mediators [54]. Several bioactive components in dietary foods like proteins, polysaccharides, and polyphenols have anti-inflammatory potentials, via regulating the secretion of inflammatory (IL-1 $\beta$, IL-6, and TNF- $\alpha$ ) and anti-inflammatory cytokines (IL-10 and TGF- $\beta$ ). Thus, the secretion levels of these cytokines can be directly used to reflect the antiinflammatory potential of assessed targets. The previous results showed that the secretion levels of IL-1 $\beta$, IL-6, and TNF- $\alpha$ were enhanced, when the RAW 264.7 macrophages were exposed to LPS [20]. Using these indicators, the mung protein hydrolysate [19], casein glycopeptide hydrolysate [50], and strawberry polysaccharides [22] were regarded to have anti-inflammatory function because they were able to reduce the levels of IL-1 $\beta$, IL-6 and TNF- $\alpha$ but increase the levels of IL-10. Two previous studies have also used the secretion levels of inflammatory cytokines IL-1 $\beta$, IL-6, and TNF- $\alpha$ of macrophages as indicators to 
identify the anti-inflammatory effects of polyphenols from sea buckthorn [21] and citrus peel [55]. It is worth noting that LPS-induced cellular inflammation can also be observed in IEC-6 cells. For example, bovine lactoferrin had anti-inflammatory function in the stimulated IEC- 6 cells by reducing the mRNA levels or protein expression of IL-1 $\beta$, IL- 6 , and TNF- $\alpha$ [24]. In addition, when IEC- 6 cells were induced by LPS, the levels of TNF- $\alpha$ and IL-1 $\beta$ were 330 and $279 \mathrm{pg} / \mathrm{mL}$, respectively; however, when $\beta$-carotene $(50 \mu \mathrm{mol} / \mathrm{L})$ was used to treat the cells, the levels of TNF- $\alpha$ and IL- $1 \beta$ were reduced by $45 \%$ and $55 \%$, respectively [23]. It is now known that the effect of cytokines on inflammation in cells is closely related to the expression of extracellular signaling pathway proteins. For the NF- $\kappa B$ signaling pathway, in response to LPS stimulation, phosphorylation of $\mathrm{I} \kappa \mathrm{B} \alpha$ causes the translocation of the free p65 subunit into the nucleus, triggering a series of cytokine secretion [56]. P38 and JNK proteins of MAPK signaling pathways are important in cellular inflammation [30]. These proteins are key elements to the transmission of signals from the cell surface to the nucleus, and an inhibition of these proteins can effectively prevent the occurrence of cell inflammation. Thus, it was observed that p-p65 and p-p38 protein expressions were significantly inhibited when the two polysaccharides from Pleurotus eryngii were used to treat LPS-induced macrophages [57]. When LPS-induced IEC-6 cells were treated with $\beta$-carotene, the relative phosphorylation level of p38 protein was decreased from 0.7 to 0.3 [23]. In the LPS-induced macrophages, casein glycopeptide hydrolysates also showed anti-inflammatory effect by inhibiting the expression of TLR4 and p-p65 proteins [50]. In consistent with these mentioned studies [23,50,57], this study also found that the two hydrolysates possessed anti-inflammatory activities to the LPS-stimulated cells via mediating cytokine secretion, together with a regulation on protein expression in the target signaling pathway.

\section{Conclusions}

The results from this study indicated that the enzymatic oligochitosan-glycation of casein incorporated oligochitosan molecules into the protein target, and thus brought about enhanced anti-inflammatory activities for the obtained glycated casein hydrolysates to the LPS-induced IEC-6 cells. Overall, the glycated casein hydrolysates had no cytotoxic effect on the cells but could alleviate the LPS-induced inflammation by increasing the secretion of two anti-inflammatory mediators, decreasing the secretion of three pro-inflammatory mediators, and down-regulating the expression of three inflammation-related proteins. Moreover, the glycated casein hydrolysates were more effective than the unglycated casein hydrolysates at producing these anti-inflammatory functions. Thus, the protein glycation using oligochitosan and transglutaminase might be a potential way to endow protein hydrolysates with higher anti-inflammatory potential in the intestine to antagonize the LPS-induced inflammation in intestinal epithelial cells, demonstrating this modification is applicable to generate protein ingredients with higher healthcare function in the body.

Author Contributions: N.C. performed the experiment, obtained, analyzed, and compiled data, and wrote the manuscript. L.W. and Q.Z. analyzed data. X.-H.Z. carried out the idea, designed this study, provided funds, and corrected the manuscript. J.S. wrote the final manuscript. All authors have read and agreed to the published version of the manuscript.

Funding: This study was funded by the Natural Science Foundation of Guangdong Province (Project No. 2021A1515011200), Scientific Research Foundation of Guangdong University of Petrochemical Technology (Project No. 2020rc026), and Independent Research and Development Projects of Maoming Laboratory (Project No. 2021ZZ003).

Institutional Review Board Statement: Not applicable.

Informed Consent Statement: Not applicable.

Data Availability Statement: All data are contained within the article.

Acknowledgments: The authors thank the anonymous reviewers for their valuable advice. 
Conflicts of Interest: The authors declare no conflict of interest.

\section{References}

1. Zhu, C.Y.; Wang, X.P.; Zhao, X.H. Property modification of caseinate responsible to transglutaminase-induced glycosylation and crosslinking in the presence of a degraded chitosan. Food Sci. Biotechnol. 2015, 24, 843-850. [CrossRef]

2. Liu, X.L.; Song, C.L.; Chen, J.P.; Liu, X.; Ren, J.; Zheng, X.Q. Preparation and evaluation of new glycopeptides obtained by proteolysis from corn gluten meal followed by transglutaminase-induced glycosylation with glucosamine. Foods 2020,9 , e555. [CrossRef] [PubMed]

3. Liu, C.; Pei, R.; Heinonen, M. Faba bean protein: A promising plant-based emulsifier for improving physical and oxidative stabilities of oil-in-water emulsions. Food Chem. 2022, 369, e130879. [CrossRef]

4. Liu, J.; Chen, W.M.; Shao, Y.H.; Zhang, J.L.; Tu, Z.C. The mechanism of the reduction in allergenic reactivity of bovine alphalactalbumin induced by glycation, phosphorylation and acetylation. Food Chem. 2020, 310, e125853. [CrossRef] [PubMed]

5. Liu, J.; Wan, Y.; Ren, L.; Li, M.; Lv, Y.; Guo, S.; Waqar, K. Physical-chemical properties and in vitro digestibility of phosphorylated and glycosylated soy protein isolate. Lwt- Food Sci. Technol. 2021, 152, e112380. [CrossRef]

6. Fu, Y.; Zhang, Y.; Soladoye, O.P.; Aluko, R.E. Maillard reaction products derived from food protein-derived peptides: Insights into flavor and bioactivity. Crit. Rev. Food Sci. Nutr. 2020, 60, 3429-3442. [CrossRef]

7. Oste, R.E.; Dahlqvist, A.; Sjoestroem, H.; Noren, O.; Miller, R. Effect of Maillard reaction products on protein digestion. In vitro studies. J. Agric. Food Chem. 1986, 34, 355-358. [CrossRef]

8. Song, C.L.; Zhao, X.H. Rheological, gelling and emulsifying properties of a glycosylated and cross-linked caseinate generated by transglutaminase. Int. J. Food Sci. Technol. 2013, 48, 2595-2602. [CrossRef]

9. Song, C.L.; Zhao, X.H. Structure and property modification of an oligochitosan-glycosylated and crosslinked soybean protein generated by microbial transglutaminase. Food Chem. 2014, 163, 114-119. [CrossRef]

10. Fu, M.; Zhao, X.H. Structure and property changes of transglutaminase-induced modification of sodium caseinate in the presence of oligochitosan of 5 kDa. Int. J. Food Prop. 2016, 19, 2596-2607. [CrossRef]

11. Fu, M.; Zhao, X.H. Modified properties of a glycated and cross-linked soy protein isolate by transglutaminase and an oligochitosan of 5 kDa. J. Sci. Food Agr. 2017, 97, 58-64. [CrossRef] [PubMed]

12. Shi, J.; Zhao, X.H. Chemical features of the oligochitosan-glycated caseinate digest and its enhanced protection on barrier function of the acrylamide-injured IEC-6 cells. Food Chem. 2019, 290, 246-254. [CrossRef] [PubMed]

13. Wang, X.P.; Ma, C.M.; Zhao, X.H. Activity of the peptic-tryptic caseinate digest with caseinate oligochitosan-glycation in rat intestinal epithelial (IEC-6) cells via the Wnt/beta-catenin signaling pathway. Chem.-Biol. Interact. 2020, 328, e109201. [CrossRef] [PubMed]

14. Murakami, A.; Ohigashi, H. Targeting NOX, iNOS and COX-2 in inflammatory cells: Chemoprevention using food phytochemicals. Int. J. Cancer. 2007, 121, 2357-2363. [CrossRef]

15. Rhee, S.H. Lipopolysaccharide: Basic biochemistry, intracellular signaling, and physiological impacts in the gut. Intest. Res. 2014, 12, 90-95. [CrossRef]

16. Shi, Z.; Dun, B.; Wei, Z.; Liu, C.; Tian, J.; Ren, G.; Yao, Y. Peptides released from extruded adzuki bean protein through simulated gastrointestinal digestion exhibit anti-inflammatory activity. J. Agric. Food Chem. 2021, 69, 7028-7036. [CrossRef]

17. Chandrasekaran, C.V.; Sundarajan, K.; Edwin, J.R.; Gururaja, G.M.; Mundkinajeddu, D.; Agarwal, A. Immune-stimulatory and anti-inflammatory activities of Curcuma longa extract and its polysaccharide fraction. Pharmacogn. Res. 2013, 5, 71-79. [CrossRef]

18. Lin, C.C.; Li, C.W.; Shih, Y.T.; Chuang, L.T. Antioxidant and anti-inflammatory properties of lower-polymerized polyphenols in oolong tea. Int. J. Food Prop. 2013, 17, 752-764. [CrossRef]

19. Diao, J.; Chi, Z.; Guo, Z.; Zhang, L. Mung bean protein hydrolysate modulates the immune response through NF-kappaB pathway in lipopolysaccharide-stimulated RAW 264.7 macrophages. J. Food Sci. 2019, 84, 2652-2657. [CrossRef]

20. Gao, R.; Shu, W.; Shen, Y.; Sun, Q.; Bai, F.; Wang, J.; Li, D.; Li, Y.; Jin, W.; Yuan, L. Sturgeon protein-derived peptides exert anti-inflammatory effects in LPS-stimulated RAW 264.7 macrophages via the MAPK pathway. J. Funct. Foods. 2020, 72, e104044. [CrossRef]

21. Jiang, F.; Guan, H.; Liu, D.; Wu, X.; Fan, M.; Han, J. Flavonoids from sea buckthorn inhibit the lipopolysaccharide-induced inflammatory response in RAW 264.7 macrophages through the MAPK and NF-kappaB pathways. Food Funct. 2017, 8, 1313-1322. [CrossRef] [PubMed]

22. Liu, C.J.; Lin, J.Y. Protective effects of strawberry and mulberry fruit polysaccharides on inflammation and apoptosis in murine primary splenocytes. J. Food Drug Anal. 2014, 22, 210-219. [CrossRef]

23. Yang, Y.; Li, R.; Hui, J.; Li, L.; Zheng, X. $\beta$-Carotene attenuates LPS-induced rat intestinal inflammation via modulating autophagy and regulating the JAK2/STAT3 and JNK/p38 MAPK signaling pathways. J. Food Biochem. 2021, 45, e13544. [CrossRef] [PubMed]

24. Kong, X.; Yang, M.; Guo, J.; Feng, Z. Effects of bovine lactoferrin on rat intestinal epithelial cells. J. Pediatr. Gastroenterol. Nutr. 2020, 70, 645-651. [CrossRef] [PubMed]

25. Li, L.; Wan, G.; Han, B.; Zhang, Z. Echinacoside alleviated LPS-induced cell apoptosis and inflammation in rat intestine epithelial cells by inhibiting the mTOR/STAT3 pathway. Biomed. Pharmacother. 2018, 104, 622-628. [CrossRef]

26. Kidd, B.L.; Urban, L.A. Mechanisms of inflammatory pain. Br. J. Anaesth. 2001, 87, 3-11. [CrossRef] 
27. Ji, Z.; Mao, J.; Chen, S.; Mao, J. Antioxidant and anti-inflammatory activity of peptides from foxtail millet (Setaria italica) prolamins in HaCaT cells and RAW 264.7 murine macrophages. Food Biosci. 2020, 36, e100636. [CrossRef]

28. Ryu, B.; Qian, Z.J.; Kim, S.K. Purification of a peptide from seahorse, that inhibits TPA-induced MMP, iNOS and COX-2 expression through MAPK and NF-kappaB activation, and induces human osteoblastic and chondrocytic differentiation. Chem.-Biol. Interact. 2010, 184, 413-422. [CrossRef]

29. Yang, Y.; Huang, C.; Lin, X.; Wu, Y.; Ouyang, W.; Tang, L.; Ye, S.; Wang, Y.; Li, W.; Zhang, X.; et al. 0.005\% Preservative-free latanoprost induces dry eye-like ocular surface damage via promotion of inflammation in mice. Investig. Ophthalmol. Vis. Sci. 2018, 59, 3375-3384. [CrossRef]

30. You, B.H.; Chae, H.S.; Song, J.; Ko, H.W.; Chin, Y.W.; Choi, Y.H. $\alpha$-Mangostin ameliorates dextran sulfate sodium-induced colitis through inhibition of NF-kappaB and MAPK pathways. Int. Immunopharmacol. 2017, 49, 212-221. [CrossRef]

31. Mazur-Bialy, A.I.; Pochec, E.; Zarawski, M. Anti-Inflammatory properties of irisin, mediator of physical activity, are connected with TLR4/MyD88 signaling pathway activation. Int. J. Mol. Sci. 2017, 18, e701. [CrossRef] [PubMed]

32. Cian, R.E.; Hernandez-Chirlaque, C.; Gamez-Belmonte, R.; Drago, S.R.; Sanchez de Medina, F.; Martinez-Augustin, O. Molecular action mechanism of anti-inflammatory hydrolysates obtained from brewers' spent grain. J. Sci. Food Agric. 2020, 100, 2880-2888. [CrossRef] [PubMed]

33. Shi, J.; Zhao, X.H.; Fu, Y.; Lametsch, R. Transglutaminase-mediated caseinate oligochitosan glycation enhances the effect of caseinate hydrolysate to ameliorate the LPS-induced damage on the intestinal barrier function in IEC-6 cells. J. Agric. Food Chem. 2021, 69, 8787-8796. [CrossRef] [PubMed]

34. Lynch, J.M.; Barbano, D.M. Kjeldahl nitrogen analysis as a reference method for protein determination in dairy products. J. AOAC Int. 1999, 82, 1389-1398. [CrossRef] [PubMed]

35. Elson, L.A.; Morgan, W.T. A colorimetric method for the determination of glucosamine and chondrosamine. Biochem. J. 1933, 27, 1824-1828. [CrossRef] [PubMed]

36. Zhang, Q.; Li, L.; Lan, Q.; Li, M.; Wu, D.; Chen, H.; Liu, Y.; Lin, D.; Qin, W.; Zhang, Z.; et al. Protein glycosylation: A promising way to modify the functional properties and extend the application in food system. Crit. Rev. Food Sci. Nutr. 2019, 59, 2506-2533. [CrossRef] [PubMed]

37. Shi, J.; Fu, Y.; Zhao, X.H.; Lametsch, R. Glycation sites and bioactivity of lactose-glycated caseinate hydrolysate in lipopolysaccharide-injured IEC-6 cells. J. Dairy Sci. 2021, 104, 1351-1363. [CrossRef]

38. Nooshkam, M.; Varidi, M.; Verma, D.K. Functional and biological properties of Maillard conjugates and their potential application in medical and food: A review. Food Res. Int. 2020, 131, e109003. [CrossRef]

39. Yang, R.; Zuo, P.; Zhang, M.; Meng, D.; Wang, B.; Zhen, T. Transglutaminase induced oligochitosan glycosylation of ferritin as a novel nanocarrier for food bioactive molecules. Food Hydrocolloids 2019, 94, 500-509. [CrossRef]

40. Hrynets, Y.; Ndagijimana, M.; Betti, M. Transglutaminase-catalyzed glycosylation of natural actomyosin (NAM) using glucosamine as amine donor: Functionality and gel microstructure. Food Hydrocolloids 2014, 36, 26-36. [CrossRef]

41. Zhan, J.; Li, G.; Tan, B. Optimization of hemoglobin chitosan glycosylation conditions and structural characteristics and functions of glycosylated hemoglobin after an in vitro digestion. J. Aquat. Food Prod. Technol. 2021, 30, 794-805. [CrossRef]

42. Nasri, M. Protein hydrolysates and biopeptides: Production, biological activities, and applications in foods and health benefits. A review. Adv. Food Nutr. Res. 2017, 81, 109-159. [CrossRef] [PubMed]

43. Kumar, D.; Chatli, M.K.; Singh, R.; Mehta, N.; Kumar, P. Antioxidant and antimicrobial activity of camel milk casein hydrolysates and its fractions. Small Ruminant Res. 2016, 139, 20-25. [CrossRef]

44. Rahimi, M.; Ghaffari, S.M.; Salami, M.; Mousavy, S.J.; Niasari-Naslaji, A.; Jahanbani, R.; Yousefinejad, S.; Khalesi, M.; MoosaviMovahedi, A.A. ACE-inhibitory and radical scavenging activities of bioactive peptides obtained from camel milk casein hydrolysis with proteinase K. Dairy Sci. Technol. 2016, 96, 489-499. [CrossRef]

45. Yu, Z.; Yin, Y.; Zhao, W.; Liu, J.; Chen, F. Anti-diabetic activity peptides from albumin against $\alpha$-glucosidase and $\alpha$-amylase. Food Chem. 2012, 135, 2078-2085. [CrossRef]

46. Kim, S.E.; Kim, H.H.; Kim, J.Y.; Kang, Y.I.; Woo, H.J.; Lee, H.J. Anticancer activity of hydrophobic peptides from soy proteins. BioFactors 2000, 12, 151-155. [CrossRef] [PubMed]

47. Duarte, J.; Vinderola, G.; Ritz, B.; Perdigon, G.; Matar, C. Immunomodulating capacity of commercial fish protein hydrolysate for diet supplementation. Immunobiology 2006, 211, 341-350. [CrossRef]

48. Ndiaye, F.; Vuong, T.; Duarte, J.; Aluko, R.E.; Matar, C. Anti-oxidant, anti-inflammatory and immunomodulating properties of an enzymatic protein hydrolysate from yellow field pea seeds. Eur. J. Nutr. 2012, 51, 29-37. [CrossRef]

49. Ahn, C.-B.; Je, J.-Y.; Cho, Y.-S. Antioxidant and anti-inflammatory peptide fraction from salmon byproduct protein hydrolysates by peptic hydrolysis. Food Res. Int. 2012, 49, 92-98. [CrossRef]

50. Cheng, X.; Gao, D.; Chen, B.; Mao, X. Endotoxin-binding peptides derived from casein glycomacropeptide inhibit lipopolysaccharide-stimulated inflammatory responses via blockade of NF-kappaB activation in macrophages. Nutrients 2015, 7 , 3119-3137. [CrossRef]

51. Iskandar, M.M.; Dauletbaev, N.; Kubow, S.; Mawji, N.; Lands, L.C. Whey protein hydrolysates decrease IL-8 secretion in lipopolysaccharide (LPS)-stimulated respiratory epithelial cells by affecting LPS binding to Toll-like receptor 4. Br. J. Nutr. 2013, 110, 58-68. [CrossRef] 
52. Shi, J.; Zhao, X.H. Effect of caseinate glycation with oligochitosan and transglutaminase on the intestinal barrier function of the tryptic caseinate digest in IEC-6 cells. Food Funct. 2019, 10, 652-664. [CrossRef] [PubMed]

53. Shi, J.; Zhang, Q.; Zhao, X.H.; Wang, L. The impact of caseinate oligochitosan-glycation by transglutaminase on amino acid compositions and immune-promoting activity in BALB/c mice of the tryptic caseinate hydrolysate. Food Chem. 2021, 350, e129302. [CrossRef] [PubMed]

54. Chang, M.; Chang, L.; Chang, H.M.; Chang, F. Intestinal and extraintestinal cancers associated with inflammatory bowel disease. Clin. Colorectal Canc. 2018, 17, e29-e37. [CrossRef]

55. Ha, S.K.; Park, H.Y.; Eom, H.; Kim, Y.; Choi, I. Narirutin fraction from citrus peels attenuates LPS-stimulated inflammatory response through inhibition of NF-kappaB and MAPKs activation. Food Chem. Toxicol. 2012, 50, 3498-3504. [CrossRef]

56. Soleimani, A.; Rahmani, F.; Ferns, G.A.; Ryzhikov, M.; Avan, A.; Hassanian, S.M. Role of the NF-kappaB signaling pathway in the pathogenesis of colorectal cancer. Gene 2020, 726, e144132. [CrossRef] [PubMed]

57. Ma, G.; Kimatu, B.M.; Yang, W.; Pei, F.; Zhao, L.; Du, H.; Su, A.; Hu, Q.; Xiao, H. Preparation of newly identified polysaccharide from Pleurotus eryngii and its anti-inflammation activities potential. J. Food Sci. 2020, 85, 2822-2831. [CrossRef] 